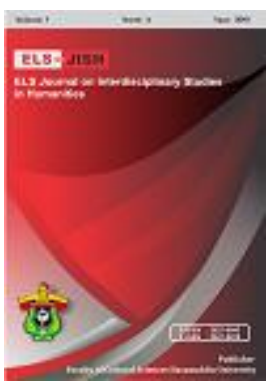

ELS-JISH

ELS Journal on Interdisciplinary Studies on Humanities

Volume 1 Issue 3, 2018

ISSN (print) : 2621-0843

ISSN (online) : 2621-0835

Homepage : http://journal.unhas.ac.id/index.php/jish

\title{
The Students' Perceptions of Creating Videos to Engage Them in Speaking
}

\author{
Anida $^{1}$, Andi Patmasari ${ }^{2}$ \\ apatmasari@gmail.com ${ }^{2}$
}

\begin{abstract}
This research investigates the students' perceptions of creating videos to engage them in speaking. This research employed a descriptive method. The population of this research was the third year students of Social Program of SMAN 1 Soppeng in the academic year 2017/2018. This research used purposive sampling, taking XII IPS 1 totaling 25 students as the sample. The instruments of this research were questionnaire and interview. The results of this research showed that creating videos has many advantages in engaging the students to speak English. Recording the conversation or dialogue is a fun activity for them although they feel nervous for the first few minutes, a few minutes later, they feel very much enjoying recording their activities and performance with their friends. Creating videos seems to be interesting and motivating the students to speak fluently. The students stated that they can see their expressions, gestures, and their mistakes by replaying their videos, so it will make them aware of their weakness and their mistakes. It creates self-learning and self-evaluation for the students. It makes the students motivated to improve their speaking skills. Thus, it is concluded that the students have positive perceptions on the effectiveness of creating videos in engaging them to speak English.
\end{abstract}

Keywords: Speaking, Perceptions, Creating Videos

How to cite: Anida \& Patmasari, A. (2018). The students' perceptions of creating videos to engage them in speaking. ELS Journal on Interdisciplinary Studies in Humanities, 1(3), 272-287.

\section{Introduction}

English is one language among languages in the world that is used as an international language. Nowadays the need for learning English has increased in every country including in Indonesia. In Indonesia, English is, by status, taught as a foreign language. It becomes one of the compulsory subjects in schools. It has been taught from primary school to secondary school not only in a formal institution but also non-formal institution. In addition, it is one of the subjects that are tested at the UNBK (Ujian Nasional Berbasis Komputer) or Computer-Based National Exam for junior and senior high schools. That is why it is very important to learn English.

English is taught as an integrated subject to develop the students' language competences. It is learned by the students in order to communicate. Thus, speaking becomes one of the important skills to master. Its success is measured in terms of the ability to carry out the conversation in an interactive process. Despite it is significant, using English for daily activity is something very rare. It is only used in the classroom and some particular requirements in a proficiency test. Furthermore,

\footnotetext{
${ }^{12}$ SMA Negeri 1 Soppeng, Indonesia
} 
Anida. 1(3): 272 - 287

Yletyinen (2004) said that in EFL classroom, the learner learns the language in an environment where there is little natural use of the language. This situation is also reflected in Indonesia.

One of the aims of the teaching of English as a second or foreign language is to make the learners able to communicate information effectively in spoken English (Brown and Yule, 1983). Regarding the statement, the English teachers must have the hard responsibility as they are demanded to have teaching technique in order to solve the problems faced by the students in learning English. The teachers must be able to arrange their assignment effectively. They are demanded to motivate the students in order to learn English well. The students are expected to be competent users of English in communicating with others. For example, in teaching speaking, they are expected to be able to do and realize the speech, such as opening and closing the conversation.

Speaking plays an important role in the process of language learning in the classroom. But speaking class is often perceived as a boring class because the teachers just applied the same technique all the time, namely practicing the dialogue in front of the class. Most English teachers spend their time forcing their students to speak in the classroom and not giving students many free areas in speaking outside the classroom. Some students feel nervous to speak in front of the classroom. They prefer to improvise their imagination, feeling, opinion and creativity through speaking outside the classroom. To solve the problems, the English teachers need to create an atmosphere in which students can be more engaged and motivated especially in taking parts in any speaking activities. If the students are motivated, their speaking skill will develop gradually.

The role of the teacher in teaching speaking skill is very important. The teachers must be able to get the students interested in learning. So, they can actively engage in speaking. The teachers need to be creative, to avoid boring teaching technique and media. There are various teaching techniques and media that could be applied to teach speaking. Widdowson (1985) explained that the act of speaking normally in the course of natural communicative interaction involves not only the use of gesture, the movement of the muscles of the face, and indeed of the whole body. Related to the statements, creating videos seems to be one of the interesting techniques. Moreover, Rice (1993) said that students may love creating videos because it is interesting, challenging, and stimulating.

There are some advantages of creating videos. Aksel and Kahraman (2014) found that students become aware of the fact that technology can be used efficiently while learning a foreign language. They also found that with the help of the VPAs (Video Project Assignments), students have an opportunity to think creatively, reflect on their learning, collaborate with their peers and learn by participating actively. This is in line with Jensen, Mattheis, and Johnson (2011) who stated that video projects foster learners' autonomy and enable them to practice the target language in a collaborative, enjoyable, and motivating atmosphere.

Sihem (2013) stated that oral practice is a very important activity in the language classroom because it is the unique opportunity for the learners to express himself freely. Sihem (2013) also concluded that video technique is very important in teaching English because it helps to improve the students' speaking skills. Nikitina (2009) emphasized that with the help of video projects, language learners have a chance to practice the target language in a more meaningful way and to develop 
useful strategies that can ease their learning process. Moreover, Kuswardani and Wahyuni (2013) concluded that recording activities in speaking English through a video is very effective to be used in the English learning process as the students could see and realize their weakness or their mistakes.

Despite the numerous research have been conducted to investigate the issue, more research need to be done to investigate this topic. The result of this research are important as they can help both the teachers and the students. The teachers can take the findings of this research into consideration in developing techniques and media to enhance the students' speaking skills. The students can reflect their perceptions and practices regarding the issue. The current research, therefore, aims to investigate the students' perceptions of creating videos to engage them in speaking after they had created videos for speaking assignments for two semesters in the third grade.

\section{Method}

This research employed a descriptive method. According to Gay, Mills, and Airasian (2006), "descriptive research also referred to as survey research, determines and describe the way things are". Furthermore, they stated that descriptive research involves collecting data to test hypotheses or to answer questions about people opinions on some topic or issue.

The population of this research was the third year students of Social Program of SMAN 1 Soppeng in the academic year 2017/2018. The number of population was 125 students. There were five classes and class XII IPS 1 was chosen as the sample of this research. In this research, purposive sampling approach was used to investigate the students' perceptions of creating videos. According to Gay, Mills, and Airasian (2006), "purposive sampling, also referred to as judgment sampling, involves selecting a sample the researcher believes to be representative of a given population".

In order to know the students' perceptions of creating videos, questionnaires were used and distributed as the main instrument and interview was used as followup activity to support the questionnaires and know the reasons behind the students' answers on the questionnaires. The questionnaires used in this research were structured or closed-ended questionnaire. The structured item provides a list of alternative responses from which the respondent selects. Many respondents will not take the time to respond items to free response items or will give unclear or useless responses, so the interview is used to know the reasons behind the students' answers on the questionnaires. The interview can produce in-depth data not possible with the questionnaires.

Questionnaires consisting of three sections were constructed. The first section is the students' perceptions of speaking skill. There are five questions in this section, the most important skill for the students, what the students think about their speaking skill, the students' main difficulty in speaking, the opportunity to speak, and the time allotted for speaking. The second section is the students' perceptions of their videos. In this section, the students were asked about the frequency of creating videos, the students' feeling excited, happy, and motivated of being recorded, the students' experience of creating videos, and the students' awareness of speaking skills through creating videos. The third section is the students' perceptions of creating videos. This section is used to confirm creating videos as an effective and enjoyable 
Anida. 1(3): 272 - 287

technique in speaking and the advantages of creating videos such as engage and encourage students to speak up, self-learning and self-evaluation, and motivate students to improve their speaking skills.

\section{Findings and Discussion}

The findings of the research are informed by two important sources of the data, questionnaire and interview. The following sections present the result drawn from data analyses and the discussion of the findings.

\subsection{Findings}

\subsubsection{The Students' Perceptions of Speaking}

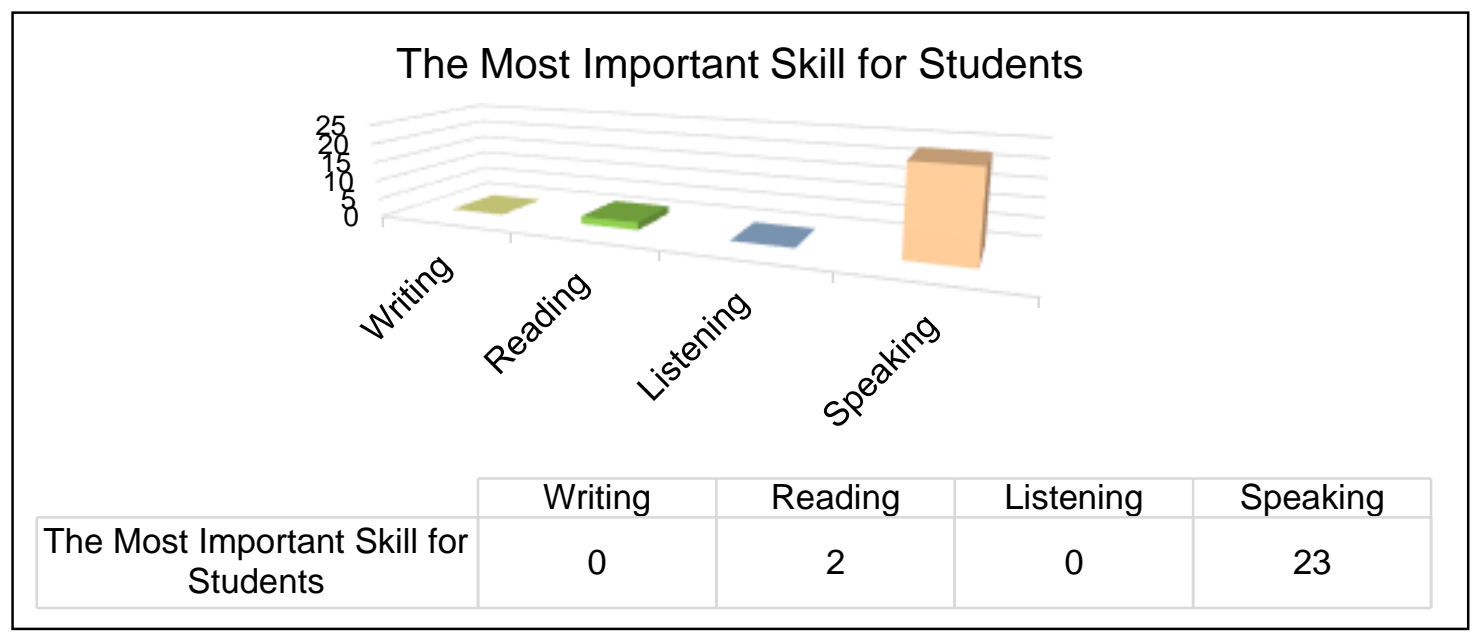

\section{Figure 1. The Most Important Skill for Students}

Figure 1 indicates that when the students were asked for their opinions regarding the most important skill for them, 23 students (92\%) chose speaking as the most important skill, whereas only 2 students (8\%) chose reading as the most important skill and no one chose listening and writing. The students who chose speaking as the most important skill said that the main goal in studying English is to communicate with another people in another country and mastering English especially speaking seems to be a symbol for labelling the educated elite in Indonesia. It can be reviewed by the students' statements in the interview section. As they stated:

"Jika kita menguasai bahasa Inggris terutama jika kita mampu berbahasa Inggris dengan fasih, kita akan terlihat lebih bergengsi." (If we master English especially if we are able to speak English fluently, we will look more prestigious.) (Student 1: April 27 ${ }^{\text {th }}, 2018$ )

"Because the main goal in studying English is to speak with another people in another country." (Student 2: April 27 ${ }^{\text {th }}, 2018$ ) 


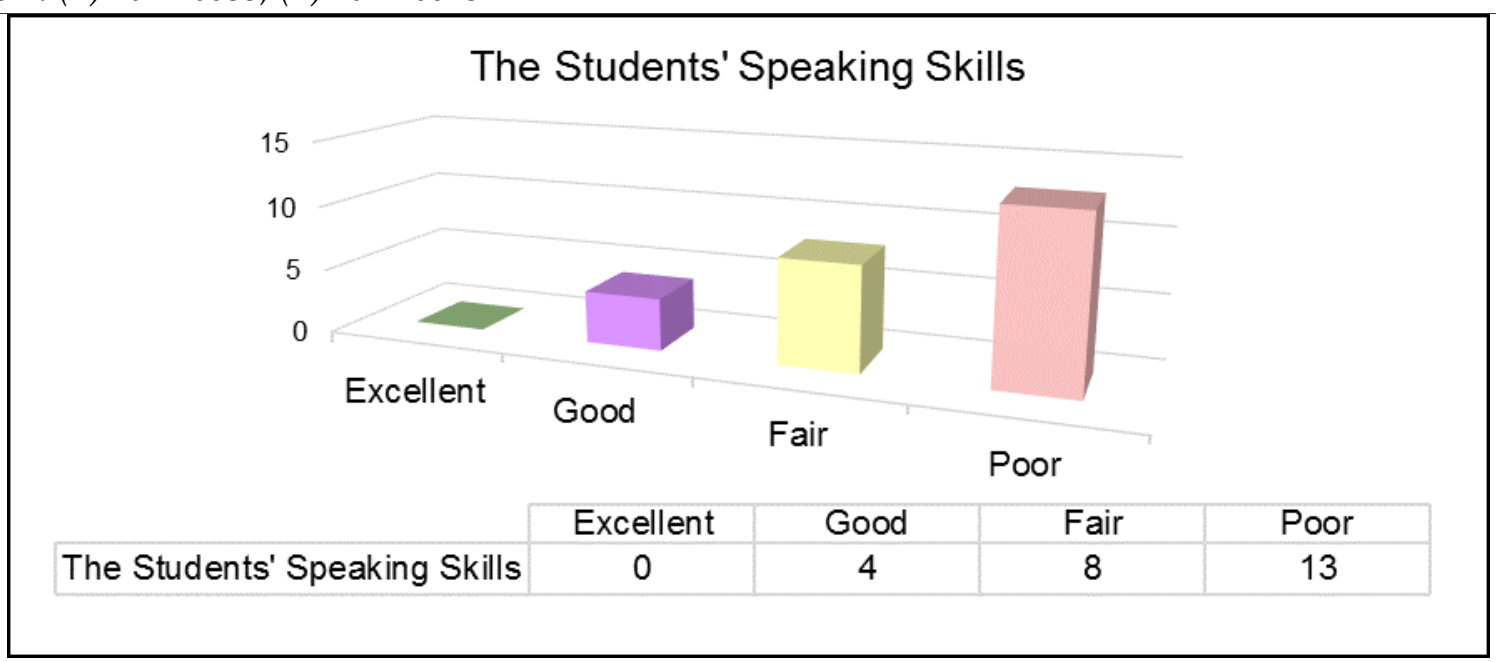

\section{Figure 2. The Students' Speaking Skills}

Figure 2 shows us 13 students (52\%) thought that their speaking skills are poor, while 8 students (32\%) thought that their speaking skills are fair, and only 4 students $(16 \%)$ thought that their speaking skills are good. The students who felt their speaking skills are poor said that speaking not only as the most important skill for them but also the most difficult skill to master. It can be reviewed by the students' statements in the interview section. As they argued:

"Kemampuan berbicara kami masih rendah karena selain yang paling penting untuk dipelajari, itu juga yang paling susah dikuasai." (Our speaking skill is poor because besides it is the most important skill to learn, speaking is also the most difficult skill to master.) (Student 1: April 27 ${ }^{\text {th }}, 2018$ )

Untuk bisa fasih dalam berbahasa Inggris, kita harus selalu menggunakannya tetapi itu sangat susah karena kata-kata dalam bahasa Inggris yang kami ketahui masih kurang. (To be fluent in English, we always have to use it but it is very difficult because the words in English that we know are still lacking.) (Student 3: April 27 ${ }^{\text {th }}, 2018$ )

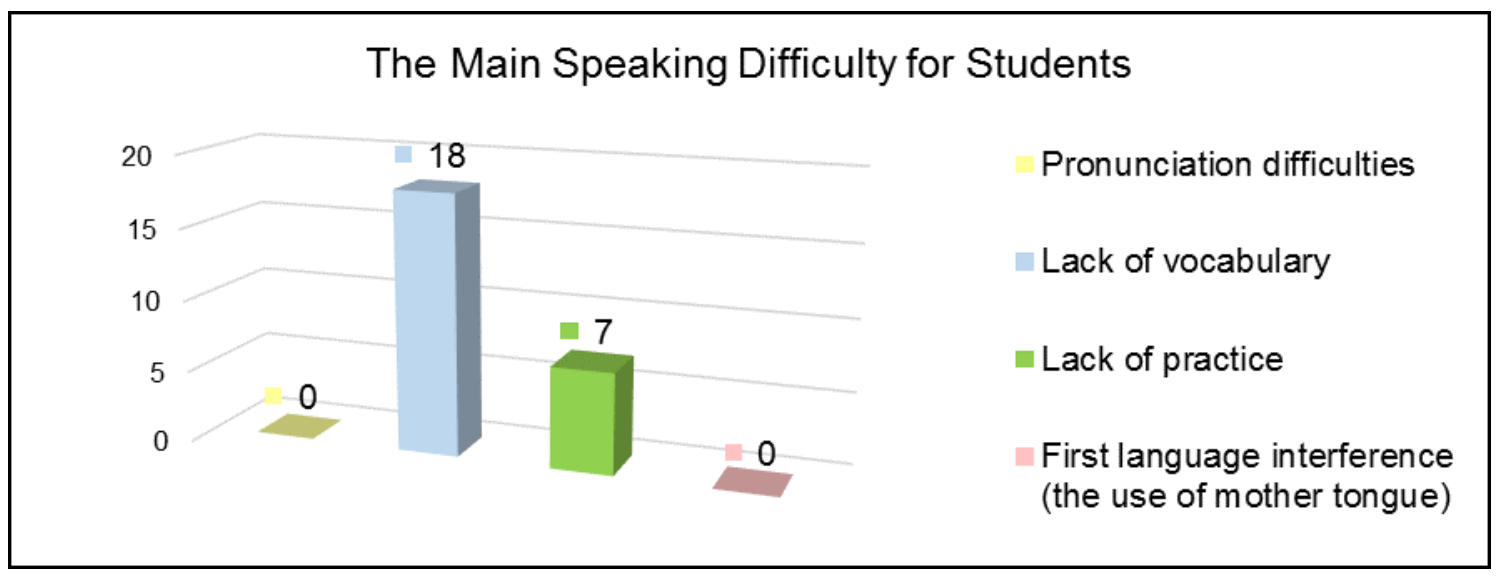

Figure 3. The Main Speaking Difficulty for Students

Out of 25 students, the majority of students, 18 students $(72 \%)$ reported that the lack of vocabulary is their main speaking problem, while 7 students $(28 \%)$ reported that lack of practice is their main problem in speaking. The students who reported 
Anida. 1(3): 272 - 287

that the lack of vocabulary is their main speaking problem said that they usually forget some of the English words when they want to speak. It can be reviewed by the students' statements in the interview section. As they said:

"Karena sangat sulit menghafal banyaknya kosakata dalam bahasa Inggris. Dan kosakata itu tidak hanya perlu dihafal tetapi juga harus selalu diulangi setiap hari." (Because it is very difficult to memorize the vocabulary in English and the vocabulary not only needs to be memorized but also must be repeated every day.) (Student 1: April 27 ${ }^{\text {th }}, 2018$ )

"We usually forget the English words when I want to produce some utterances." (Student 2: April 27 ${ }^{\text {th }}, 2018$ )

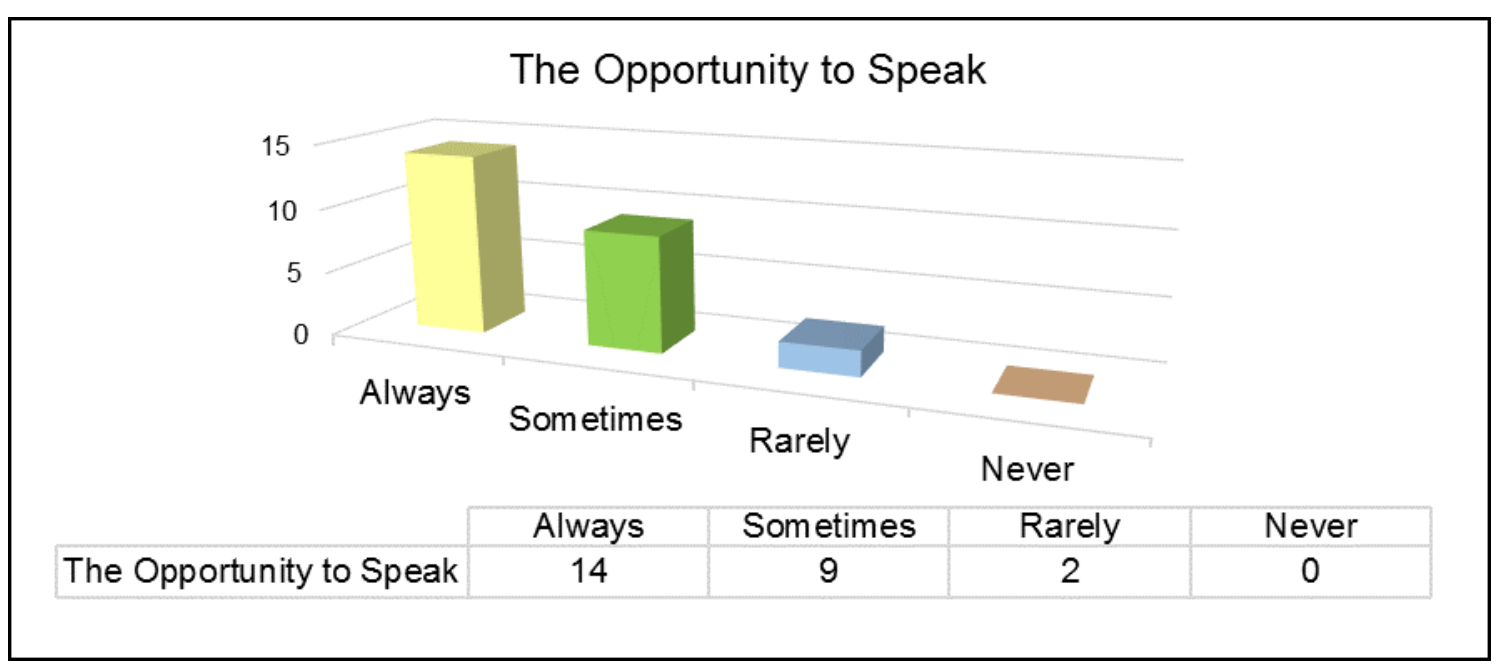

\section{Figure 4. The Opportunity to Speak}

It can be concluded from figure 4 that out of 25 students, $9(36 \%)$ claimed that their teacher sometimes gave them opportunity to speak, 14 students $(56 \%)$ claimed that their teacher always gave them opportunity to speak, and only $2(8 \%)$ claimed that their teacher rarely gave them opportunity to speak. The students who claimed their teacher always gave them opportunity to speak said that they are happy to do it because they can practice using English. It can be reviewed by the students' statements in the interview section. As they argued:

"Hampir setiap kali dalam pertemuan di kelas, kita selalu diberi kesempatan untuk berbicara dengan menggunakan bahasa Inggris." (Almost every meeting in the classroom, we are always given the opportunity to speak English.) (Student 3: April 27 ${ }^{\text {th }}, 2018$ )

"Maybe, every we meet in the classroom. But we like it because we can practice." (Student 2: April 27 ${ }^{\text {th }}, 2018$ ) 


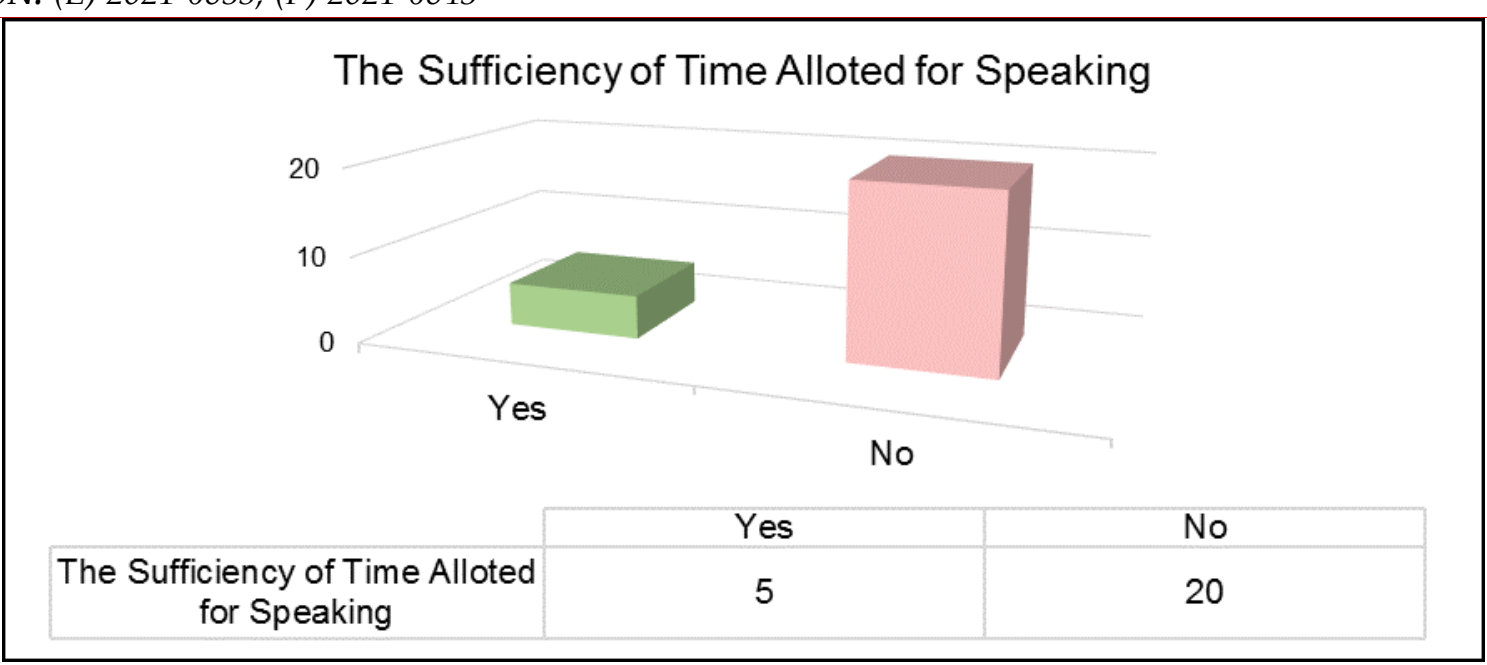

\section{Figure 5. The Sufficiency of Time Allotted for Speaking}

According to the figure 5, most of the students agreed that the time allotted for speaking was sufficient and only 5 students answered that the time allotted for speaking was not sufficient. The students who answered the time allotted for speaking was not sufficient said that there is only a few time for practicing and speaking in the classroom, they need more time to practice. It can be reviewed by the students' statements in the interview section. As they argued:

"Waktu yang dialokasikan untuk berbicara di dalam kelas masih kurang. Selain waktu untuk berbicara, kita juga membutuhkan waktu untuk menghafal kosakata dan mempelajari struktur kalimat." (The time allotted for speaking in the classroom is lacking. Besides the time to speak, we also need time to memorize vocabulary and learn the structure of the sentences.) (Student 3: April 27 ${ }^{\text {th }}, 2018$ )

"We also have to master the structure and vocabulary so we can be fluent in speaking English." (Student 2: April 27 ${ }^{\text {th }}, 2018$ )

\subsubsection{The Students' Perceptions of Their Videos}

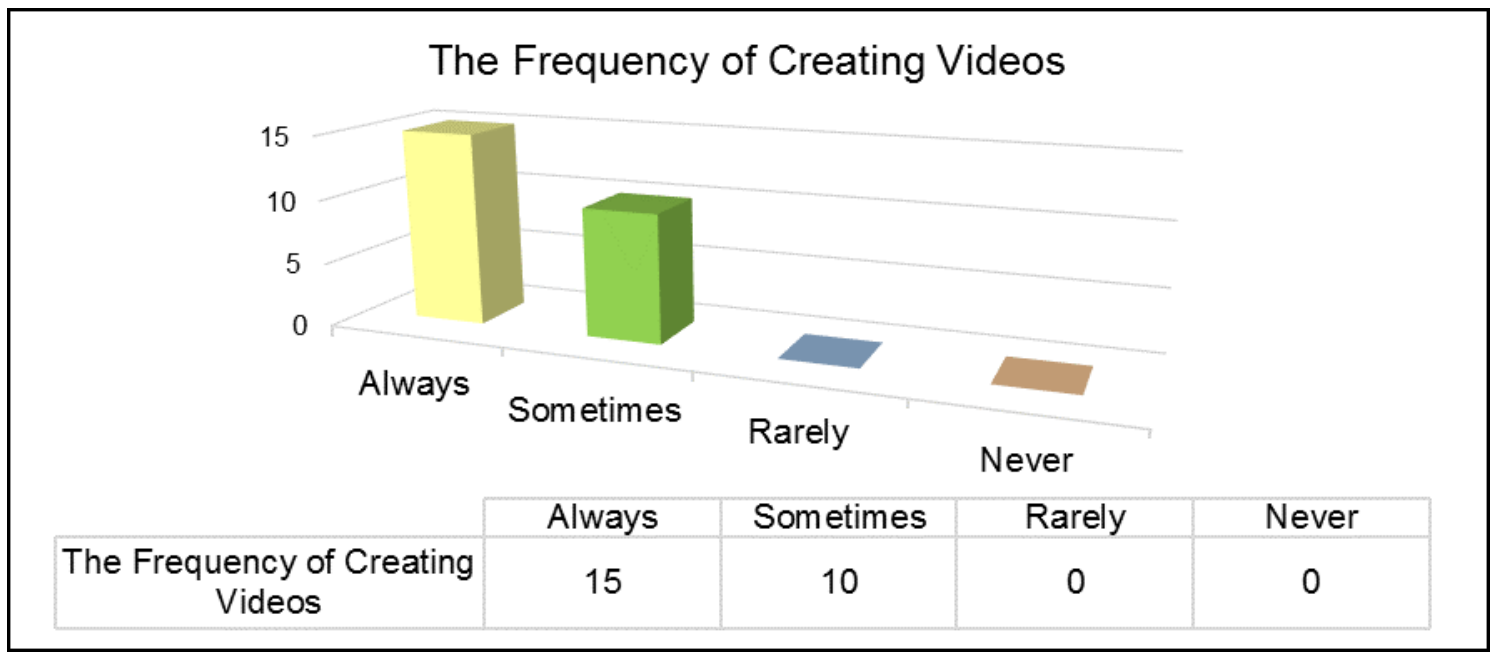

Figure 6. The Frequency of Creating Videos

Out of 25 students, $15(60 \%)$ claimed that their teacher always asked them to create videos and 10 students (40\%) claimed that their teacher sometimes asked 
Anida. 1(3): 272 - 287

them to create videos. They said that creating videos is not a boring technique so they will do it with pleasure. It can be seen from the following students' statements in the interview section. As the students said:

"Kami suka membuat video, jadi tidak masalah kalau guru selalu menyuruh kami membuat video." (We love to create videos, so it does not matter if the teacher always tells us to create videos.) (Student 1: April 27 $7^{\text {th }}, 2018$ )

"It's not boring, so we will do it whenever the teacher tells us to do it." (Student 2: April $27^{\text {th }}, 2018$ )

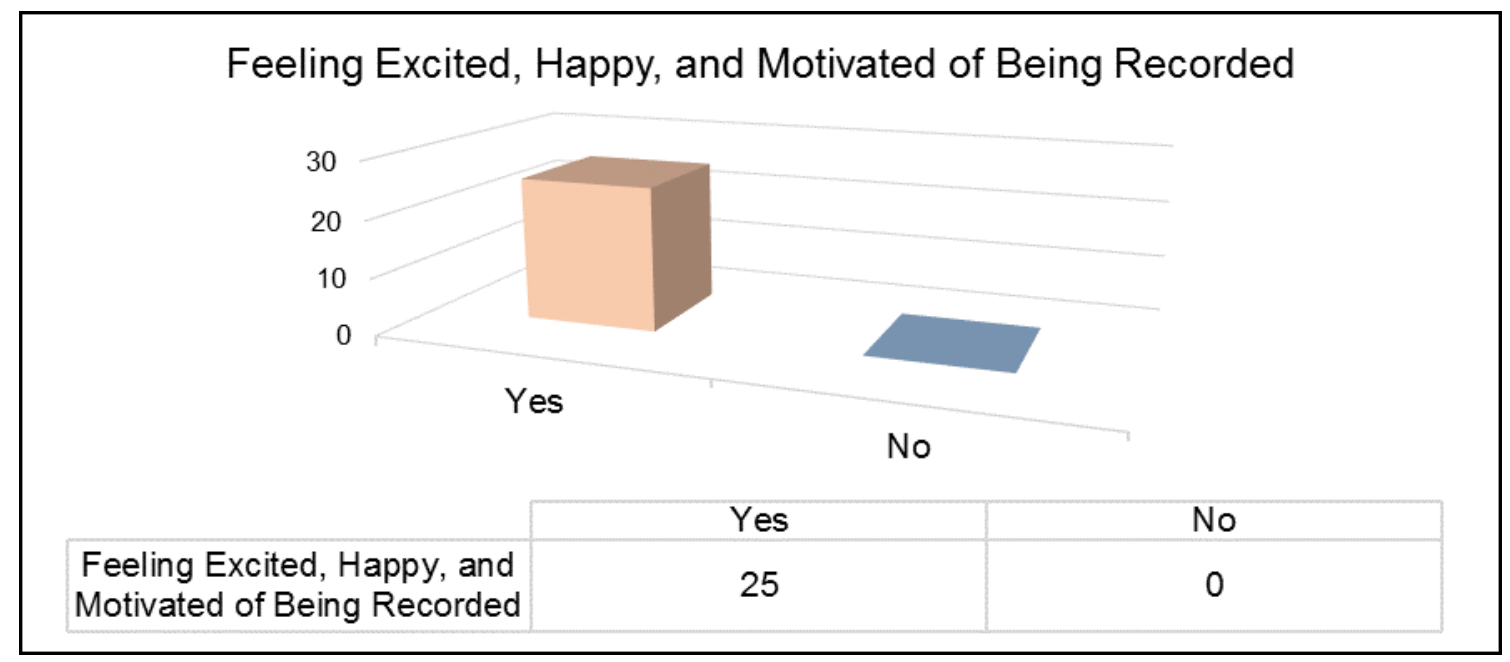

Figure 7. The Students' Feeling Excited, Happy, and Motivated of Being Recorded

It can be concluded from figure 7 that all the students felt excited, happy, and motivated of being recorded. They said that they feel happy and motivated to be recorded because they can do it anytime and anywhere and they can express themselves freely. It can be seen from the following students' statements in the interview section. As the students said:

"Kita merasa senang dan termotivasi untuk direkam karena kita bisa melakukannya kapan saja dan dimana saja asalkan kita mempunyai kamera." (We feel excited and motivated to be recorded because we can do it anytime and anywhere as long as we have camera.) (Student 1: April 27 ${ }^{\text {th }}, 2018$ )

"Because we feel like a native speaker and we can correct our mistakes by playing our videos." (Student 2: April 27 ${ }^{\text {th }}, 2018$ )

"We feel excited because we can express ourselves freely." (Student 4: April $\left.27^{\text {th }}, 2018\right)$ 


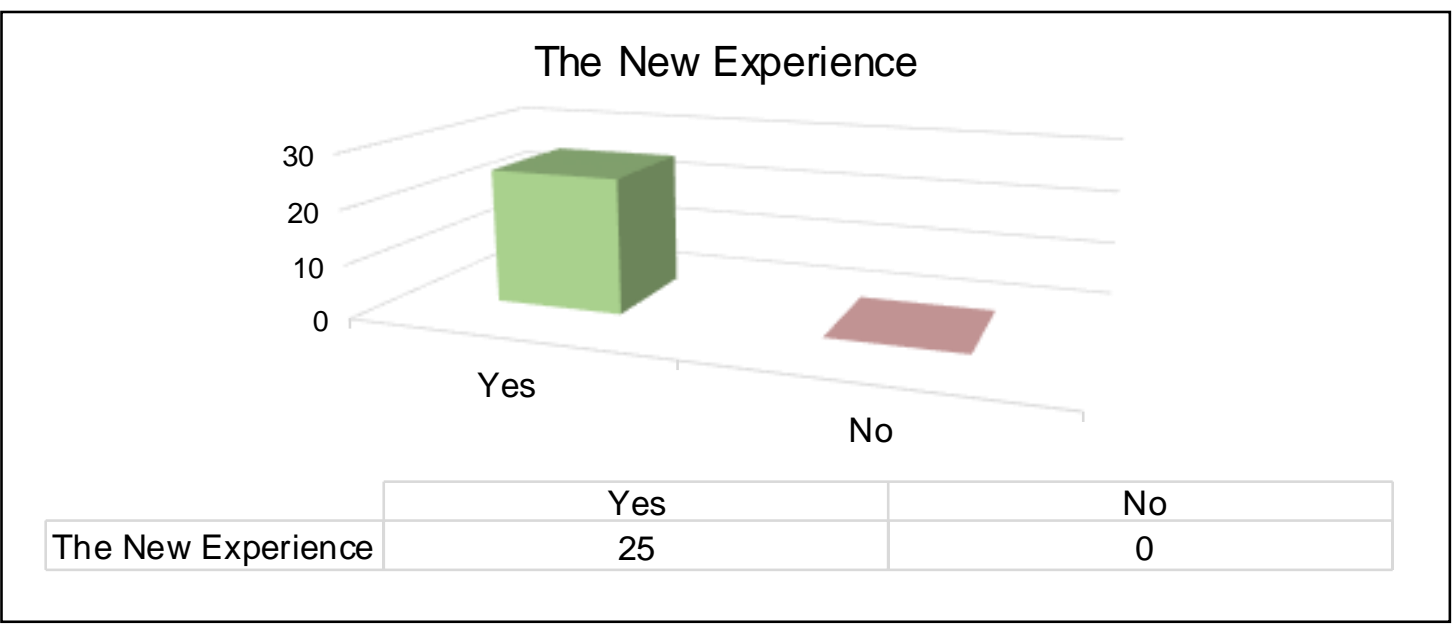

\section{Figure 8. The Students' Experience of Creating Videos}

Out of 25 students, most of them (23 students) answered that creating videos was a new experience for them, only 2 of them answered that creating video was not their new experience. They who answered creating videos was a new experience for them stated that they never do it before. It can be reviewed by the students' statements in the interview section. As they argued:

"Sebelumnya kami belum pernah disuruh untuk membuat video, jadi ini adalah pengalaman pertama kami." (Previously we have never been asked to create videos so this is our first experience.) (Student 3: April 27 ${ }^{\text {th }}, 2018$ )

"We never do it before in Junior High School." (Student 4: April 27 $7^{\text {th }}, 2018$ )

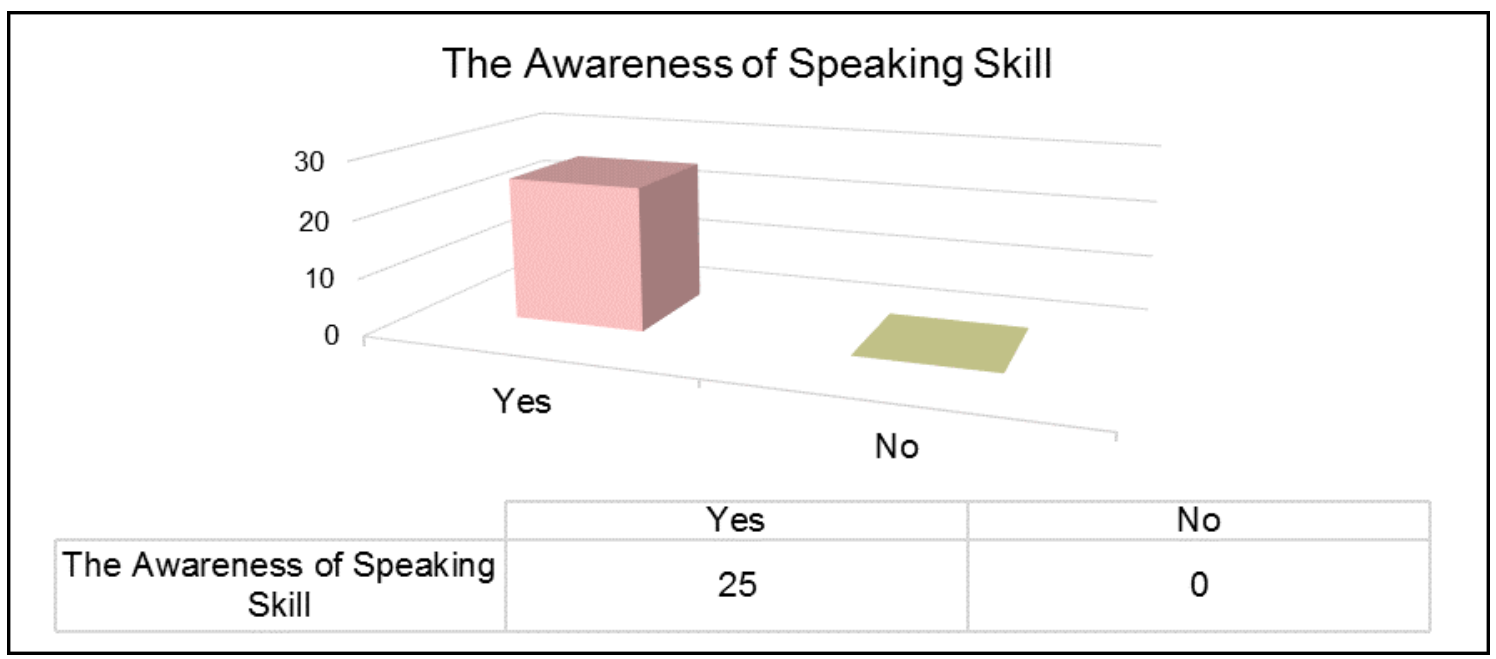

Figure 9. The Students' Awareness of Their Speaking Skills

It can be seen from the figure 9 that all the students (100\%) agreed that creating videos makes them aware of their speaking skills. They said that they can see their expressions, gestures, and their mistakes after replaying the videos and it makes them aware of their speaking skills. It can be reviewed by the students' statements in the interview section. As they argued:

"Membuat video membuat kita menyadari kemampuan berbahasa Inggris kita karena kita bisa memperhatikan kesalahan kita setelah membuat video tersebut." (Creating videos makes us aware of our English speaking skill 
Anida. 1(3): 272 - 287

because we can pay attention to our mistakes after making the videos.) (Student 1: April 27 th 2018 )

"Because we can see our expressions, gestures, and our mistakes after creating that videos." (Student 4: April $27^{\text {th }}, 2018$ )

"Karena dengan memutar kembali video yang telah dibuat, kita dapat melihat bagaimana penampilan dan kemampuan kita sebenarnya." (Because by replaying the created videos we can see how our looks and skills really are.) (Student 3: April 27 $7^{\text {th }}, 2018$ )

\subsubsection{The Students' Perceptions of Creating Videos}

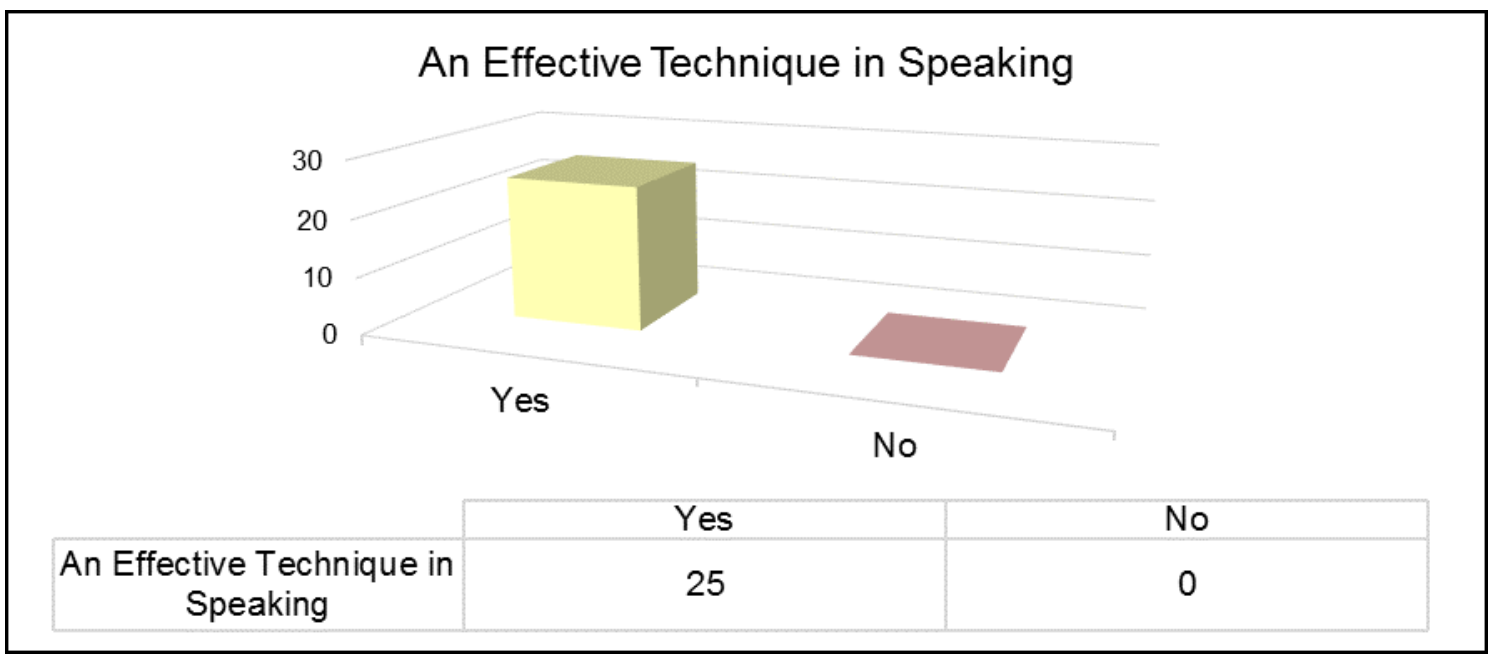

Figure 10. The Effectiveness of Creating Videos in Speaking

Figure 10 shows that all students agreed that creating videos is an effective technique in speaking. They said that students will engage in something new, like creating videos. Furthermore, they can see their speaking skills from the videos, so they think creating videos is an effective technique in speaking. It can be reviewed by the students' statements in the interview section. As they stated:

"Membuat video adalah teknik yang efektif karena kita bisa menguji kemampuan diri sendiri, tetapi hal itu juga harus diikuti dengan latihan berbicara secara rutin." (Creating videos is an effective technique because we can examine our own skills but it should be followed by regular speaking practice.) (Student 1: April 27 $7^{\text {th }}, 2018$ )

"Yes, I think it is an effective way but it must be followed by practicing more." (Student 2: April 27 $7^{\text {th }}, 2018$ )

"Kita sebagai siswa selalu tertarik dengan sesuatu yang baru seperti membuat video dan kita juga bisa melihat bagaimana kemampuan berbicara kita dari video, jadi membuat video adalah teknik yang cukup efektif." (We as students are always interested in something new like creating videos and we can also see how our speaking skills from the videos so making videos is an effective technique.) (Student 3: April 27 ${ }^{\text {th }}, 2018$ ) 


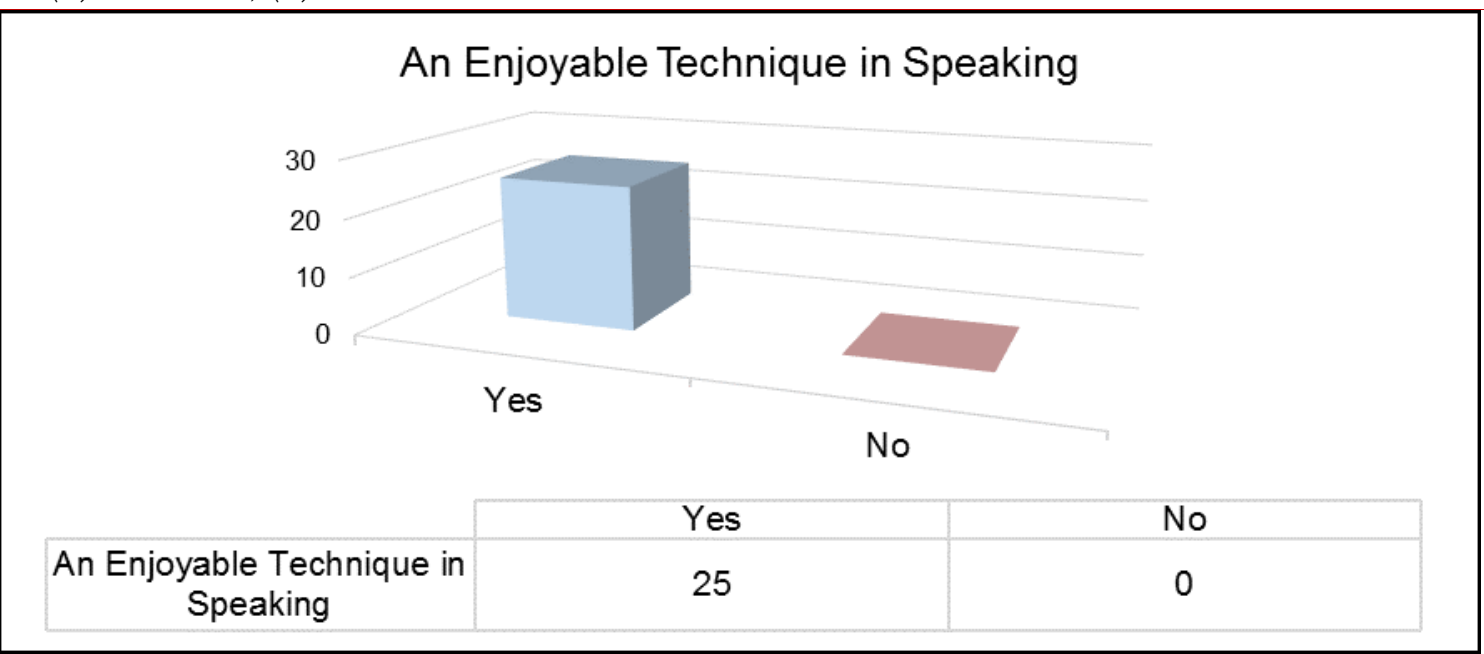

Figure 11. The Enjoyment of Creating Videos in Speaking

Out of 25 students, all students (100\%) agreed that creating videos is an enjoyable technique in speaking. They stated that they feel fun when learning and practicing their speaking skills through creating videos. They also can record videos wherever they like and explore their speaking skills. It can be proved by the students' statements in the interview section. As they argued:

"Membuat video merupakan teknik yang menyenangkan karena kita bisa membuatnya kapan saja. Apabila perasaan kita sedang tidak fokus, maka itu bisa ditunda sampai kita merasa fokus dan siap." (Creating videos is a fun technique because we can create it anytime. If our feelings are not focused, it can be postponed until we feel focused and ready to do it.) (Student 1: April $\left.27^{\text {th }}, 2018\right)$

"Because we can explore our speaking skills and compare our videos with our friends' videos." (Student 2: April 27 $7^{\text {th }}, 2018$ )

"Karena kita dapat merekam video dimanapun tempat yang kita sukai, jadi itu sangat menyenangkan." (Because we can record videos wherever we like, so it is really fun.) (Student 3: April $27^{\text {th }}, 2018$ )

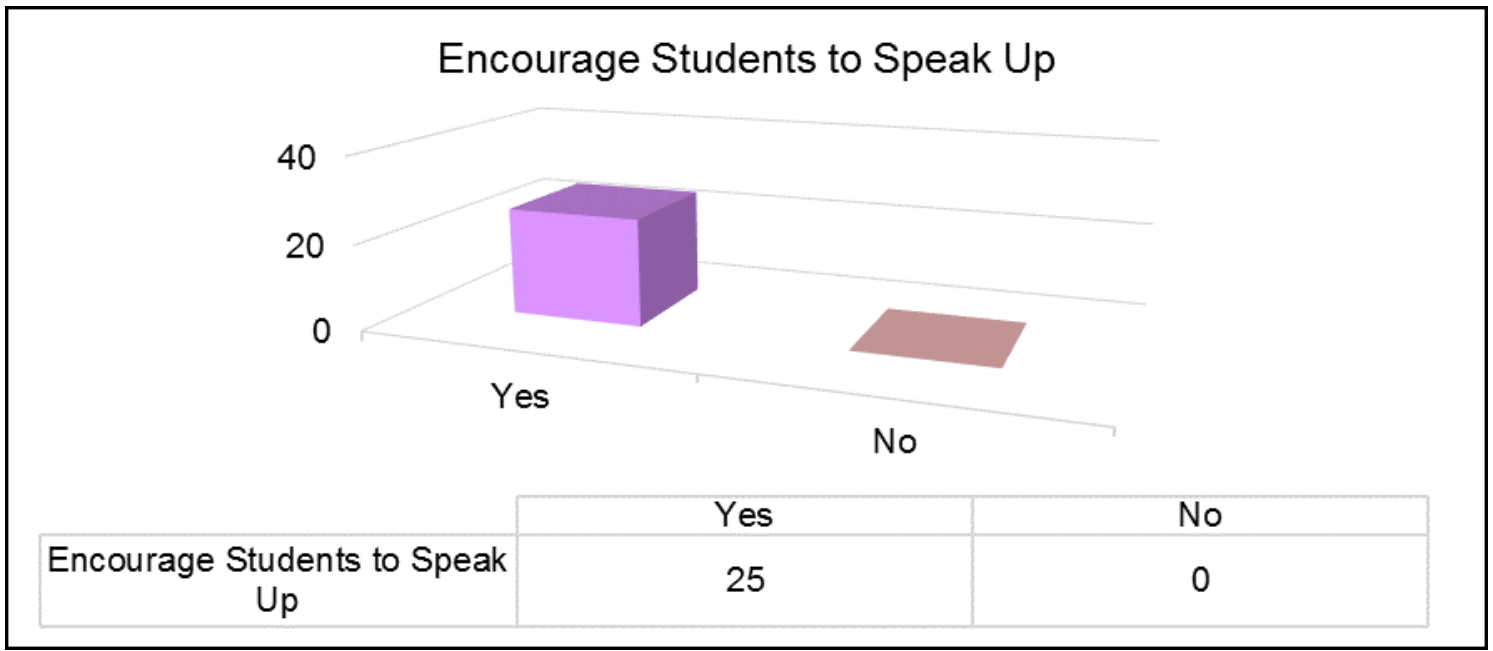

Figure 12. The Encouragement of Students to Speak Up through Creating Videos 
Anida. 1(3): 272 - 287

Figure 12 shows that all students believed that creating videos engages and encourages them to speak up. They stated that creating videos engages them to speak up because their teacher and their friends can see their videos, so they want to show their best performance. They will try to do their best to correct their pronunciation and enhance their speaking skills. It can be proved by the result of the interview. As the students stated:

"Membuat video mendorong kita untuk berbicara karena orang dapat melihat video kita, jadi kita harus percaya diri dan menampilkan kemampuan terbaik kita." (Creating videos encourage us to speak because people can see our videos so we have to be confident and show our best skills.) (Student 1: April $\left.27^{\text {th }}, 2018\right)$

"Because by creating videos, we can detect our mistakes so we can fix it and improve our skills." (Student 2: April 27 ${ }^{\text {th }}, 2018$ )

"Kita akan merasa malu kalau ada salah pengucapan di video, jadi kita harus berusaha supaya pengucapan kita bagus supaya teman-teman yang melihat video itu tidak akan menertawai kita." (We will feel embarrassed if there is any incorrect pronunciation in the videos so we have to try to make our pronunciation good so friends who see the videos will not laugh at us.) (Student 3: April $27^{\text {th }}, 2018$ )

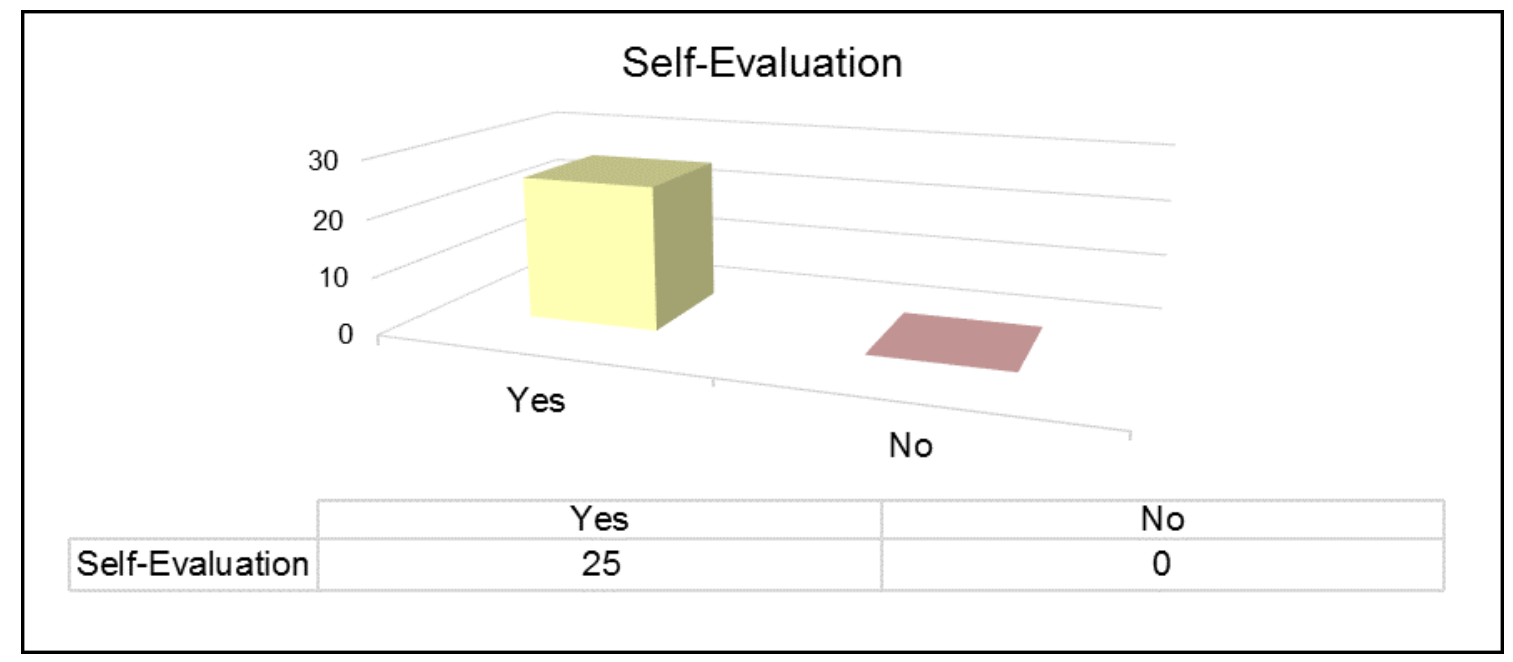

Figure 13. The Advantage of Creating Videos Due to Self-Evaluation

It can be seen from figure 13 that all the students (100\%) concurred that creating videos is advantageous due to self-evaluation. They said that they can see their performance and it makes them aware of how good or bad their speaking skills. Besides that, other people can see and give their opinions and comments about their performance and their speaking skills. It can be reviewed by the students' statement in the interview section. As the students stated:

"Membuat video bermanfaat untuk evaluasi diri karena dengan membuat video kita bisa menilai diri sendiri dan kita juga bisa membuat beberapa video lalu membandingkannya sehingga kita bisa ambil yang paling bagus." (Creating videos useful for self-evaluation because by creating videos we can assess ourselves and we can also create some videos than compare them so we can grab the best one.) (Student 1: April 27 ${ }^{\text {th }}, 2018$ ) 
"Because we can know our mistakes after we or other people see our videos and give their opinions." (Student 2: April 27 ${ }^{\text {th }}, 2018$ )

"Karena kita dapat memutar kembali video yang telah dibuat dan melihat bagaimana penampilan kita dalam video." (Because we can replay the videos that have been made and see how we look in the videos.) (Student 3: April 27 ${ }^{\text {th }}$, 2018)

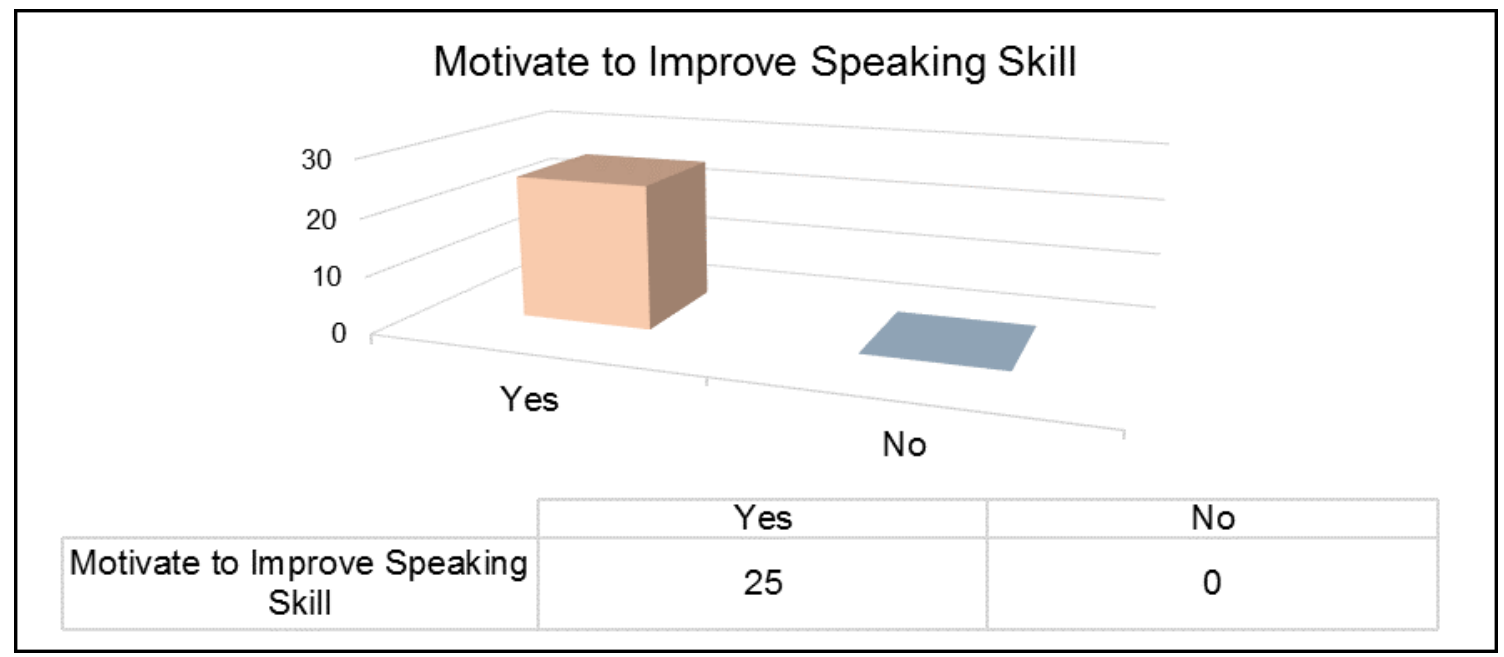

Figure 14. The Students' Motivation to Improve Their Speaking Skill through Creating Videos

It can be concluded from figure 14 above that creating videos motivates students to improve their speaking skills. They explained that everyone may see their videos, so they want to show their best speaking skill and do not want to have their bad performance in their recording. Therefore, they will practice all the times and try to memorize their dialogue to create the best performance. In this case, the students said:

"Membuat video memotivasi kita untuk meningkatkan kemampuan berbicara karena kita bisa melihat kekurangan kita saat berbicara sehingga itu bisa diperbaiki untuk menghasilkan video yang maksimal." (Creating videos motivates us to improve our speaking skills because we can see our weakness while speaking English so that it can be fixed to produce the maximum video.) (Student 1: April 27 ${ }^{\text {th }}, 2018$ )

"Creating videos motivates us to improve our speaking skills because we can repeat to create videos so we can have a perfect one." (Student 4: April $27^{\text {th }}$, 2018)

"Membuat video memotivasi kita untuk meningkatkan kemampuan berbicara karena kita akan selalu berlatih dan berusaha menghafal dialog supaya penampilan kita bagus." (Creating videos motivates us to improve our speaking skills because we will always practice and try to memorize the dialogue to make our performance good.) (Student 3: April 27 ${ }^{\text {th }}, 2018$ )

\subsection{Discussion}

The results of the analysis can be summarized into three points. First, although the students have positive beliefs that speaking is the most important skill for them, most of them are indicated not to have good English speaking skills. The reasons for 
Anida. 1(3): 272 - 287

not having good English speaking skills is that they often encounter problems in speaking English. The lack of vocabulary is their main speaking problem. It is very difficult for them to memorize the vocabulary in English. They stated that although their teacher gives them opportunity to speak, but whenever they want to speak, they always feel afraid of making mistakes and do not know how to express their ideas and their feelings in English. Besides the lack of vocabulary, the students also think the lack of practice as their speaking problem. The vocabulary not only needs to be memorized but also must be repeated every day. Practice will make their speaking skills better.

Second, this research confirms that although creating videos is a new experience for students in learning, but they feel excited, happy, and motivated of being recorded. They love to create videos, so it does not matter for them if their teacher always tells them to create videos because they can do it anytime and anywhere. They find creating video can express themselves. The use of technology in teaching and learning process has simply given education a new color of life. Technology has created opportunities for situated learning and support learning outside the classroom. This is in line with Ghavifekr and Rosdy (2015) who stated that technology-based teaching and learning is more effectively in compare to traditional classroom.

Finally, this research has proved that there are some advantages of creating videos. The students agree that creating videos is an effective technique in speaking. They can watch themselves doing speaking and they can assess their speaking skills. Because they can record videos wherever they like, so they think that creating videos is really fun. Based on the statements, it can be said that creating videos is an effective and enjoyable technique in speaking. Creating videos encourages the students to speak because they can watch their videos and they will learn their mistakes from the videos and people's comments. By doing this, they will evaluate each other. Creating videos is also useful for self-evaluation because by creating videos they can watch and see their expression, gestures, and their mistakes. They will have opportunities to view and to play or replay their videos many times so that they can learn from their mistakes. It is good for them for self-learning and selfevaluation so they can focus on their own weakness. Creating videos will motivate students to improve their speaking skills because they will practice and try to memorize the dialogue to make their performance good. They do not want to have bad performance in their recording finally they feel that they can show their speaking skill better and more confident. They feel happy evaluating what they have done due to their mistakes and their weakness can be improved consciously. It motivates students to improve their speaking skill. This finding supports Aksel's and Kahraman's (2014) finding who stated that the students had positive or neutral perceptions on the effectiveness of the VPAs (Video Project Assignment) for their foreign language classes.

\section{Conclusions}

Based on the research findings, it can be concluded that the students have positive perceptions on the effectiveness of creating videos in engaging them to speak English. The data showed that creating videos has many advantages in engaging the students to speak English. Students perceive video as a useful tool and media, especially in speaking class. Recording the conversation or dialogue is a fun activity for them although they feel nervous for the first few minutes, a few minutes 
later, they feel very much enjoying recording their activities and performance with their friends. They feel free to explore their talent and creativity and show up their skills in front of camera. Creating videos seems to be interesting and motivating students to speak fluently. The students stated that they can see their expressions, gestures, and their mistakes by replaying their videos, so it will make them aware of their weakness and their mistakes. It creates self-learning and self-evaluation for the students. It makes the students motivated to improve their speaking skills.

For the English teachers, the result of this research is one of the solutions for teaching and learning problem related to engaging students in speaking. The teachers can take the findings of this research into consideration in developing techniques and media to enhance the students' speaking skills. It is suggested that the teachers should use an attractive media to motivate the students enjoy the learning process. A pleasant classroom atmosphere and an attractive media using by a creative teacher will make the students motivated to do their best effort to enhance their speaking skills. If the students are motivated, their speaking skills will increase gradually. So, it is the task of the teachers to empower all the elements of teaching to create a fun and challenging learning and avoid boring teaching technique and media. Meanwhile, for the future researchers, it is important to carry out further research on creating videos, not only to engage and encourage the students in speaking but also empower them to be more creative and confident in speaking class. The findings can also be used as a reference to conduct further research using different research design, or language skill, or even genre.

\section{References}

Aksel, A. \& Kahraman, F.G. (2014). Video project assignments and their effectiveness on foreign language learning. Procedia-Social and Behavioural Sciences, 141, 319-324. doi: 10.1016/j.sbspro.2014.05.055

Brown, G. \& Yule, G. (1983). Teaching the Spoken Language: An Approach Based on The Analysis of Conversational English. Cambridge: Cambridge University Press.

Gay, L.R., Mills, G.E., \& Airasian, P. (2006). Education Research: Competencies for Analysis and Applications. New Jersey: Merrill Prentice Hall.

Ghavifekr, S. \& Rosdy, W.A.W. (2015). Teaching and learning with technology: Effectiveness of ICT integration in schools. International Journal of Research in Education and Science (IJRES), 1(2), 175-191.

Jensen, M., Mattheis, A., \& Johnson, B. (2011). Using student learning and development outcomes to evaluate a first-year undergraduate group video project. CBE Life Sciences Education, 11(1), 68-80.

Kuswardani, N. \& Wahyuni, R.B. (2013). Encouraging students in speaking through videoing activity. Jurnal Manajemen Resort dan Leisure, 10(1), 248-255.

Nikitina, L. (2009). Student video project as a means to practice constructivist pedagogy in the foreign language classroom. Jurnal Pendidik dan Pendidikan, Jil.(24). 165-176.

Rice, S. (1993). Teaching and learning through story and dialogue. Educational Theory, 43(1), 85-97 Retrieved from https://doi.org/10.1111/j.17415446.1993.00085.x 
Anida. 1(3): 272 - 287

Sihem, S. (2013). Using Video Techniques to Develop Students' Speaking Skill (Master's Thesis, Mohamed Khider University of Biskra, Algeria). Retrieved from http://dspace.univ-biskra.dz:8080/jspui/handle/123456789/4786

Widdowson, H. G. (1985). Teaching Language as Communication. Oxford: Oxford University Press.

Yletyinen, H. (2004). The Function of Codeswitching in EFL Classroom Discourse (Master's Thesis, University of Jyväskylä, Finland). Retrieved from https://jyx.jyu.fi/ bitstream/handle/ 123456789/7407/G0000707.pdf 